\title{
Infectious complications after surgery for a frontal meningioma
}

\author{
Rafael Garcia-Carretero
}

Hospital Universitario de Mostoles, Mostoles, Spain

\section{Correspondence to} Dr Rafael Garcia-Carretero, rgcarretero@salud.madrid.org

Accepted 12 December 2018

\section{DESCRIPTION}

A 70-year-old man was admitted to our hospital due to impaired consciousness and interruptions of his ongoing activities. On presentation, his speech was abruptly interrupted with bouts of silence, but these symptoms disappeared within a few seconds. We suspected absence seizures, and thus we recommended an electroencephalogram and both brain CT and MRI (figure 1). Neuroimaging revealed a large frontal mass, $8 \times 6 \times 8 \mathrm{~cm}$ in size, involving both hemispheres but especially the right one.

We initiated lacosamide $150 \mathrm{mcg}$ twice daily and dexamethasone $4 \mathrm{mg}$ every 6 hours to control cerebral swelling and seizures. Then he was referred to our neurosurgery department for a preoperative embolisation which was followed by a posterior craniotomy with excision of the meningioma with ultrasonic aspiration 24 hours later. ${ }^{1}$ Pathologists reported it was a grade I meningioma (benign).

The patient did not experience early complications, but 10 days after surgery he presented with a fever $\left(38^{\circ} \mathrm{C}\right)$ and absence seizures. A brain CT did not reveal any abscesses, but a sample obtained through a lumbar puncture was positive for Enterobacter cloacae; thus, we initiated piperacillin-tazobactam combination therapy (4 g every 6 hours).

However, his clinical condition worsened in the following days, with spontaneous fluid draining from the frontal wound. He underwent a new brain CT which revealed a frontal epidural empyema (figure 2).

The patient was admitted to our intensive care unit and then underwent surgical drainage. Samples of pus from the frontal wound were referred for culture. They were positive for multidrug-resistant E. cloacae and oxacillin-resistant Staphylococcus

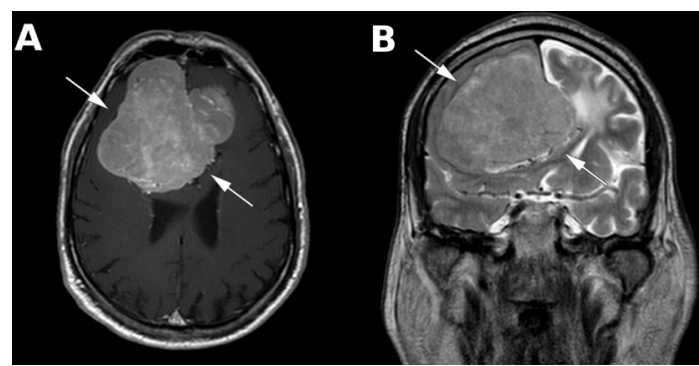

Figure 1 Brain MRI showing a large intracranial mass (arrows) in the right hemisphere, hyperintense both in T1 ( $A$, transverse plane) and T2 ( $B$, coronal plane), with perilesional oedema and mass effects but no radiological signs of hydrocephalus.

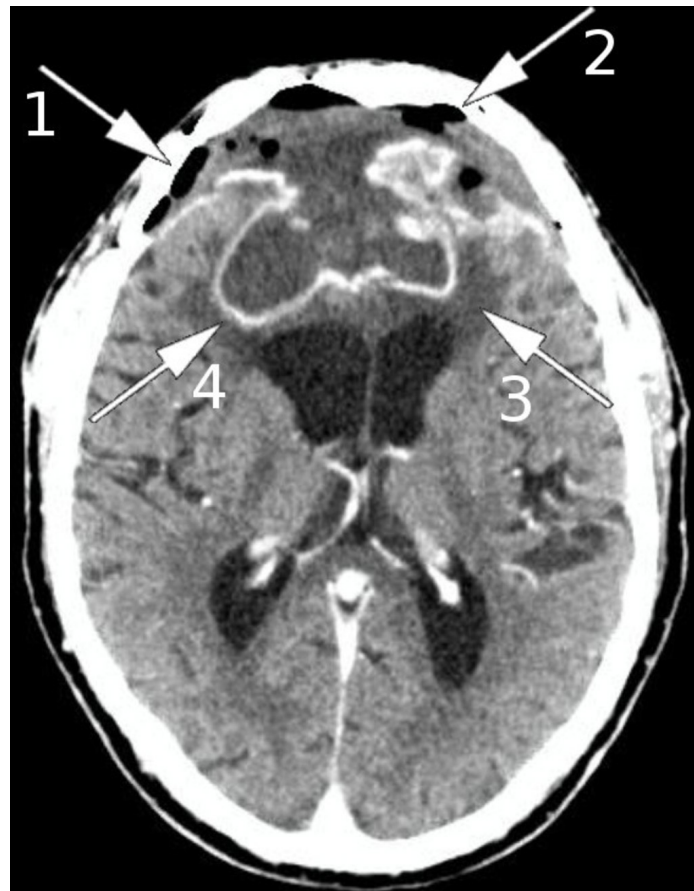

Figure 2 Brain CT showing a frontal craniotomy with a heterogeneous abscess with bubbles (arrows 1 and 2) within the cranial cavity (pneumocephalus), producing mass effects and frontal vasogenic oedema (arrows 3 and 4).

aureus; hence, vancomycin and meropenem were initiated. His fever resolved, and his clinical condition markedly improved. He was discharged 1 month after the first surgical procedure.

In a follow-up 3 months after discharge, a new brain CT did not reveal any intracranial abscesses. However, he exhibited some focal neurological deficits such as left hemiparesis, hearing loss and cognitive impairment.

Meningiomas are the second most common intracranial tumour. ${ }^{2}$ Although surgical management is the primary treatment, and the survival rate is high, some neurological sequelae related to complications may occur which decrease patients' quality of life. Therefore, some authors discourage surgical treatment in patients older than 70 years, given the high mortality and morbidity rates associated with such surgeries. $^{23}$

Regarding the risk factors of neurosurgical site infections, some publications reported the main risk factors for infection were cerebrospinal fluid leakage, indwelling catheters, non-elective surgery, dirty wounds and operative time greater 
than 4 hours. ${ }^{4}$ Staphylococcus spp was the most common pathogen in the mentioned publications.

\section{Learning points}

- Postoperative haematoma, infection, brain oedema and hydrocephalus are local complications after an intracranial surgical procedure.

- Neurological deficits may be long-term sequelae after radical excision of a meningioma.

- The older the patient, the higher the likelihood of morbidity and mortality.

- Infectious complications after cranial surgery are important events, even with strict adherence to sterile techniques. Surgeons and clinicians should be aware of risk factors in order to promptly identify such severe infections.

Contributors RGC drafted the manuscript and edited the images.
Funding The authors have not declared a specific grant for this research from any funding agency in the public, commercial or not-for-profit sectors.

Competing interests None declared.

Patient consent Obtained.

Provenance and peer review Not commissioned; externally peer reviewed.

\section{REFERENCES}

1 Raper DM, Starke RM, Henderson F, et al. Preoperative embolization of intracranial meningiomas: efficacy, technical considerations, and complications. AJNR Am J Neuroradiol 2014;35:1798-804.

2 van Alkemade $\mathrm{H}$, de Leau M, Dieleman EMT, et al. Impaired survival and long-term neurological problems in benign meningioma. Neuro Oncol 2012;14:658-66.

3 Boviatsis EJ, Bouras TI, Kouyialis AT, et al. Impact of age on complications and outcome in meningioma surgery. Surg Neurol 2007;68:407-11.

4 Dashti SR, Baharvahdat $H$, Spetzler RF, et al. Operative intracranial infection following craniotomy. Neurosurg Focus 2008;24:E10.

5 Korinek AM. Risk factors for neurosurgical site infections after craniotomy: a prospective multicenter study of 2944 patients. The french study group of neurosurgical infections, the sehp, and the c-clin paris-nord. service epidémiologie hygiène et prévention. Neurosurgery 1997;41:1073-81.

Copyright 2018 BMJ Publishing Group. All rights reserved. For permission to reuse any of this content visit

https://www.bmj.com/company/products-services/rights-and-licensing/permissions/

BMJ Case Report Fellows may re-use this article for personal use and teaching without any further permission.

Become a Fellow of BMJ Case Reports today and you can:

- Submit as many cases as you like

- Enjoy fast sympathetic peer review and rapid publication of accepted articles

- Access all the published articles

- Re-use any of the published material for personal use and teaching without further permission

For information on Institutional Fellowships contact consortiasales@bmjgroup.com

Visit casereports.bmj.com for more articles like this and to become a Fellow 